\title{
Combined Pharmacological Inhibition of Cyclophilins, FK506-Binding Proteins, Hsp90, and Hsp70 Protects Cells From Clostridium botulinum C2 Toxin
}

\author{
Katharina Ernst ${ }^{*}$, Carolin Kling ${ }^{\dagger}$, Marc Landenberger and Holger Barth* \\ Institute of Pharmacology and Toxicology, Ulm University Medical Center, Ulm, Germany
}

\section{OPEN ACCESS}

Edited by:

Flavio Rizzolio,

Università Ca' Foscari, Italy

Reviewed by:

Andrew Truman,

University of North Carolina at Charlotte, United States

Janice Eva Arlee Braun,

University of Calgary, Canada

*Correspondence:

Katharina Ernst

katharina.ernst@uni-ulm.de

Holger Barth

holger.barth@uni-ulm.de

${ }^{\dagger}$ These authors have contributed equally to this work

Specialty section:

This article was submitted to Experimental Pharmacology

and Drug Discovery,

a section of the journal

Frontiers in Pharmacology

Received: 15 August 2018 Accepted: 22 October 2018 Published: 13 November 2018

Citation:

Ernst K, Kling C, Landenberger M and Barth H (2018) Combined

Pharmacological Inhibition

of Cyclophilins, FK506-Binding Proteins, Hsp90, and Hsp70 Protects Cells From Clostridium botulinum C2

Toxin. Front. Pharmacol. 9:1287.

doi: 10.3389/fphar.2018.01287
The Clostridium botulinum C2 toxin is an exotoxin causing severe enterotoxic symptoms. The $\mathrm{C} 2$ toxin consists of the binding/translocation component C2II, and the enzymatic active component C2I. After proteolytic activation, C2lla forms heptamers that bind C2I. The C2lla/C2I complex is taken up into mammalian target cells via receptor-mediated endocytosis. Acidification of endosomes leads to conformational changes in both components. C2lla heptamers form a pore into the endosomal membrane, and C2I becomes unfolded and translocates through the narrow C2lla pores into the cytosol of the cell. Here, C2I covalently transfers an ADP-ribose moiety from its co-substrate $\mathrm{NAD}^{+}$onto $\mathrm{G}$-actin, which leads to depolymerization of F-actin resulting in rounding up of adherent cells. Translocation of C2I into the cytosol depends on the activity of the chaperones Hsp90 and Hsp70 and peptidyl-prolyl cis/trans isomerases of the cyclophilin (Cyp) and FK506-binding protein (FKBP) families. Here, we demonstrated that C2I is detected in close proximity with Hsp90, Cyp40, and FKBP51 in cells, indicating their interaction. This interaction was dependent on the concentration of C2 toxin and detected in mammalian Vero and human HeLa cells. Moreover, the present study reveals that combination of radicicol, VER-155008, cyclosporine A, and FK506, which are specific pharmacological inhibitors of Hsp90, Hsp70, Cyps, and FKBPs, respectively, resulted in a stronger inhibition of intoxication of cells with $\mathrm{C} 2$ toxin compared to application of the single inhibitors. Thus, the combination of inhibitors showed enhanced protection of cells against the cytotoxic effects of C2 toxin. Cell viability was not significantly impaired by application of the inhibitor combination. Moreover, we confirmed that the combination of radicicol, VER-155008, CsA, and FK506 in particular inhibit the membrane translocation step of C2I into the cytosol whereas receptor binding and enzyme activity of the toxin were not affected. Our findings further characterize the mode of action of Hsp90, Hsp70, Cyps, and FKBPs during membrane translocation of bacterial toxins and furthermore supply starting points for developing of novel therapeutic strategies against diseases caused by bacterial toxins that depend on Hsp90, Hsp70, Cyps, and FKBPs.

Keywords: bacterial protein toxin, PPlases, cyclophilins, FK506 binding proteins, chaperones, membrane translocation, protein interaction, specific pharmacological inhibition 


\section{INTRODUCTION}

The Clostridium botulinum C2 toxin is a bacterial exotoxin and represents the prototype of the family of clostridial binary toxins which comprises amongst others the $C$. perfringens iota toxin and the C. difficile CDT toxin (Barth and Aktories, 2011; Stiles, 2017). These toxins are secreted by the respective bacteria and consist of two non-linked proteins, the binding/translocation B-component, and the enzymatically active A-component. The B-component binds to a specific receptor on target cells and mediates the uptake of the A-component via receptor-mediated endocytosis. The B-component forms a pore into the endosomal membrane through which the A-component translocates into the cytosol. Here, the A-component covalently transfers an ADPribose moiety onto monomeric actin (G-actin), which leads to a depolymerization of the actin cytoskeleton and therefore to rounding of target cells (Reuner et al., 1987; Aktories and Wegner, 1992; Aktories et al., 2017b). All three toxins cause severe enterotoxic symptoms in humans or animals, which are the consequence of their enzymatic mode of action in cells. The C2 toxin causes necrosis and hemorrhagic lesions in the intestinal mucosa of mice (Simpson, 1982; Ohishi, 1983a,b) and fluid accumulation in the intestinal loop of pheasants and chicken (Kurazono et al., 1987). For the iota toxin, lambs and calves have been identified as common casualties for its enterotoxicity (Songer, 1996; Billington et al., 1998). C. difficile infections (CDI) are still on the rise in hospitals of Western countries and pose a severe threat due to life-threatening symptoms such as antibioticassociated diarrhea or pseudomembranous colitis. CDT has been identified as a novel virulence factor produced by hypervirulent C. difficile strains and most likely contributes to an improved colonization of $C$. difficile in the human gut (Aktories et al., 2018; Papatheodorou et al., 2018).

The prototype of clostridial toxins, $\mathrm{C} 2$ toxin is composed of the A-component $\mathrm{C} 2 \mathrm{I}$ and the B-component C2II (Ohishi, 1983a,b). After proteolytic activation of C2II, the resulting C2IIa forms ring-shaped heptamers that bind to carbohydrate structures, which have been found on the surface of all cell types, investigated so far (Barth et al., 2000; Eckhardt et al., 2000). C2I attaches to specific motifs of the C2IIa heptamer and the C2IIa/C2I complex is taken up via receptor-mediated endocytosis (Barth et al., 1998a; Blöcker et al., 2000; Kaiser et al., 2006). Acidification of the endosomal lumen results in formation of a C2IIa pore with a narrow inner diameter of 1-2 nm into the endosomal membrane (Barth et al., 2000; Schleberger et al., 2006). At least partial unfolding of C2I is required to translocate through the narrow C2IIa pore into the target cell cytosol where it ADP-ribosylates G-actin (Aktories et al., 1986; Haug et al., 2003b). We demonstrated earlier that translocation of C2I into the cytosol is facilitated not only by the C2IIa pore but requires activity of host cell chaperones and peptidyl-prolyl cis/trans isomerases (PPIases) [for review see (Schiene-Fischer, 2015; Barth and Ernst, 2016; Ernst et al., 2017b; Schopf et al., 2017)]. We identified the heat shock protein Hsp90 and Hsp70 as well as isoforms of the cyclophilin (Cyp) and FK506 binding protein (FKBPs) family, namely CypA, Cyp40, and FKBP51, as specific interaction partners for C2I. Hsp90 and Hsp70 activities are ATP-dependent and play important roles during several cellular processes such as folding, refolding, avoiding aggregation of unfolded proteins as well as protein transport, e.g., through the endoplasmic reticulum or into mitochondria (Freeman and Morimoto, 1996; Chacinska et al., 2009; Clerico et al., 2015; Schopf et al., 2017). Cyps and FKBPs catalyze the cis/trans isomerization of prolyl-bonds, which often represents a ratelimiting step in protein folding (Brandts et al., 1975; SchieneFischer, 2015). Specific pharmacological inhibition of Hsp90, Hsp70, Cyps, and FKBPs activities prevented translocation of C2I into the cytosol and protected cells from intoxication. Direct interaction between chaperones/PPIases and C2I was demonstrated and characterized in vitro by various methods including dot blot analysis, co-precipitation, and isothermal titrations calorimetry (Haug et al., 2003a, 2004; Kaiser et al., 2009, 2011, 2012; Ernst et al., 2015, 2016, 2017a). Here, we demonstrate the interaction of Hsp90, Cyp40, and FKBP51 with C2I in cells by employing a fluorescence-based proximity ligation assay (PLA). Moreover, we discovered that the simultaneous application of the various specific pharmacological inhibitors of Hsp90, Hsp70, Cyps, and FKBPs resulted in a significantly stronger inhibitory effect on C2 intoxication compared to the single application of each inhibitor. Moreover, the combined pharmacological inhibition of the chaperones/PPIases in cells resulted in a stronger inhibition of the membrane translocation of C2I into the cytosol compared to inhibition of each host cell factor alone. This might lead to novel pharmacological strategies to treat/prevent the severe enteric diseases in humans and animals that are associated with binary clostridial toxins.

\section{MATERIALS AND METHODS}

\section{Protein Expression and Purification}

The recombinant proteins C2I, C2I E389/387Q, C2IIa were purified and activated as described before (Barth et al., 1998b). In brief, recombinant proteins were overexpressed as GST-fusion proteins in E. coli BL21 cells, batch-purified and the GST-tag was cleaved with thrombin. C2IIa was activated with trypsin.

\section{Cell Culture and Intoxication Experiments}

Vero (African green monkey kidney) and HeLa cells (from DSMZ, Braunschweig, Germany) were cultured in MEM plus $10 \%$ heat-inactivated fetal calf serum (FCS) $\left(\right.$ GIBCO $^{\circledR}$ life technologies, Karlsruhe, Germany), $0.1 \mathrm{mM}$ non-essential amino acids, $1 \mathrm{mM}$ sodium pyruvate, $2 \mathrm{mM}$ L-glutamine, and $10 \%$ penicillin-streptomycin at $37^{\circ} \mathrm{C}$ and $5 \% \mathrm{CO}_{2}$. Cells were detached using trypsin and 25 cycles of reseeding were performed. For intoxication experiments, cells were seeded in 24well culture dishes and incubated with C2I and C2IIa at $37^{\circ} \mathrm{C}$ and $5 \% \mathrm{CO}_{2}$. To analyze the effect upon inhibition of host cell factors, cells were pre-incubated with the specific inhibitors cyclosporine A (CsA, inhibitor of Cyp activity, Sigma-Aldrich, Steinheim, Germany), FK506 (inhibitor of FKBP activity, Sigma-Aldrich, Steinheim, Germany), radicicol (Rad, inhibitor of the ATPbinding site of Hsp90, Sigma-Aldrich, Steinheim, Germany), 
and VER-155008 (VER, inhibitor of the ATP-binding site of Hsp70 and Hsc70, Sigma-Aldrich, Steinheim, Germany) $30 \mathrm{~min}$ prior to toxin application. Pictures of cells were taken using a Zeiss Axiovert 40CFL microscope with a Jenoptik ProGres C10 CCD camera. Toxin-specific morphological changes (i.e., cell rounding) were analyzed by determining the percentages of rounded cells by manually counting the cells per picture using ImageJ (National Institutes of Health, Bethesda, United States). Materials for cell culture were purchased from TPP Techno Plastic Products. Cell viability was measured by using MTS [3-(4, 5-dimethylthiazol-2-yl)-5-(3-carboxymethoxyphenyl)-2-(4-sulfo phenyl)-2H-tetrazolium] cyto-toxicity assay Cell Titer 96 Aqueous from Promega (Mannheim, Germany) according to the manufacturer's instructions.

\section{Immunofluorescence}

Cells were seeded in ibidi $\mu$-slide eight-well plates. After respective treatments, cells were washed and fixed with $4 \%$ paraformaldehyde (PFA) and 100\% ice-cold methanol. After permeabilization with $0.4 \%$ Triton X-100, quenching with $100 \mathrm{nM}$ glycine, and blocking with 10\% FCS, anti-C2IN serum, and subsequently fluorescence labeled secondary antibody were added. Images were obtained using iMic digital microscope (FEI Munich) and Live Acquisition 2.6 software (FEI Munich) and were processed with ImageJ software (National Institutes of Health, Bethesda).

\section{Analysis of Protein Interaction Using PLA Technology}

Cells were seeded in ibidi $\mu$-slide eight-well plates and incubated with $\mathrm{C} 2$ toxin for $1 \mathrm{~h}$ at $37^{\circ} \mathrm{C}$, washed with $\mathrm{PBS}$ and then fixed with 4\% PFA in PBS for 15 min followed by freezing methanol for $1 \mathrm{~min}$. Cells were permeabilized with Triton X-100 (0.4\% in PBS) for $5 \mathrm{~min}$, treated with $100 \mathrm{mM}$ glycine in PBS, and blocked with blocking solution (Duolink using PLA technology, Sigma-Aldrich, St. Louis, United States) for $1 \mathrm{~h}$ at $37^{\circ} \mathrm{C}$. Cells were incubated with rabbit anti C2IN (N-terminal part of C2I) serum (1:1500) and mouse anti Hsp90 antibody (1:8000) (Santa Cruz Biotechnology, Dallas, United States), mouse anti FKBP51 antibody (1:100) (Abnova, Taipei City, Taiwan), or mouse anti Cyp40 antibody (1:100) (Acris Antibodies GmbH, Herford, Germany), all diluted in antibody diluent (Duolink using PLA technology, Sigma-Aldrich, St. Louis, United States) for $1 \mathrm{~h}$ at $37^{\circ} \mathrm{C}$. Subsequently, the PLA was performed according to the manufacturer's protocol (Duolink using PLA technology, Sigma-Aldrich), as previously described (Ernst et al., 2017a). In brief, PLA secondary antibodies contain small oligonucleotide sequences, which can form a ring structure if they get in close proximity. By addition of ligase and polymerase, a rolling circle amplification can occur. Fluorescently labeled oligonucleotides that are complementary to the amplification product allow the detection of the two target proteins, which are situated in close proximity i.e., interact with each other. In addition, fluorescence-labeled secondary antibodies were added to detect Hsp90, FKBP51, and Cyp40 in these samples.

\section{Analysis of Protein Levels by Western Blotting}

After incubation of cells in the presence or absence of $\mathrm{C}^{*}$ for indicated time periods, cells were washed with PBS and then harvested in $2.5 \times$ Laemmli sample buffer. Samples were incubated for $10 \mathrm{~min}$ at $95^{\circ} \mathrm{C}$, subjected to SDSPAGE, and blotted onto a nitrocellulose membrane. Ponceau $S$ staining was performed to confirm protein transfer and comparable protein loading. After blocking the membrane with $5 \%$ nonfat dry milk in PBS containing $0.1 \%$ Tween-20 (PBST), membrane was cut to allow simultaneous detection of Hsp90 (Santa Cruz, Heidelberg, Germany), FKBP51 (Bethyl Montgomery, United States) and Cyp40 (Thermo Scientific, Waltham, United States) via specific primary antibodies and secondary antibodies (Santa Cruz, Heidelberg, Germany) and enhanced chemiluminescence (ECL) system. The membrane was stripped and Hsp70 (Enzo Life Sciences, Lörrach, Germany) was detected as described above.

\section{Flow Cytometry}

Vero cells were detached from culture dishes with $10 \mathrm{mM}$ EDTA in PBS, washed twice with PBS, and then were resuspended in MEM + FCS with or without the combination of Rad, CsA, FK506, and VER. Typically, $2 \times 10^{5}$ cells per sample were used. Cells were incubated for $30 \mathrm{~min}$ at $37^{\circ} \mathrm{C}$ and subsequently for $5 \mathrm{~min}$ on ice. C2IIa plus either C2I-DyLight488 or C2I*-DyLight488 were added for 10 min to allow binding. Cells were washed with PBS and were then subjected to flow cytometry using a BD FACSCelesta flow cytometer and the BD FACSDiva ${ }^{\mathrm{TM}}$ software. DyLight 488 excitation was performed with a blue laser $(488 \mathrm{~nm})$ and emitted fluorescence detected with a $530 \mathrm{~nm}(530 / 30)$ bandpass filter. For data analysis and generation of fluorescence histograms from gated cell populations Flowing Software v2.5.1 (Perttu Terho, Turku Centre for Biotechnology, Finland) was used. Line smoothing (level 3) was applied to fluorescence histograms. Proteins were labeled with DyLight 488 according to the manufacturer's recommendations (Thermo Scientific, Waltham, United States). Excess dye was removed with Micro Bio-Spin 6 columns (Bio-Rad Laboratories, Munich, Germany).

\section{Toxin Translocation Assay}

This assay was performed as described earlier (Barth et al., 2000). In short, cells were pre-incubated with the respective chaperone/PPIase inhibitors in bafilomycin A1 (BafA1, inhibitor of v-ATPase, Calbiochem ${ }^{\circledR}$, Bad Soden, Germany)-containing medium. BafA1 prevents the normal toxin uptake via endosomal route. Then, cells were incubated on ice and toxin was added for $20 \mathrm{~min}$ to allow binding but inhibit internalization. Cells were exposed to warm acidic medium for $5 \mathrm{~min}$ at $37^{\circ} \mathrm{C}$, which leads to pore formation by C2IIa directly into the cytoplasmic membrane and translocation of C2I through the C2IIa pore into the host cell cytosol. As control, cells were treated with neutral medium. Medium was removed and replaced by fresh BafA1-containing medium. 
Cell morphology was observed as a specific endpoint of intoxication.

\section{Analysis of in vitro Enzyme Activity}

Vero cell lysate (20 $\mu \mathrm{g}$ of protein) was pre-incubated for $30 \mathrm{~min}$ at $37^{\circ} \mathrm{C}$ with Rad, CsA, FK506 and VER or left untreated for control. C2I and $10 \mu \mathrm{M}$ biotin-NAD ${ }^{+}$were added for $20 \mathrm{~min}$ at $37^{\circ} \mathrm{C}$. ADP-ribosylated, i.e., biotin-labeled - G-actin was detected by Western blotting using streptavidin-peroxidase.

\section{RESULTS}

\section{C2I Is Found in Close Proximity With Hsp90, Cyp40, and FKBP51 in Cells}

Interaction between C2I and Hsp90, Cyp40, and FKBP51, respectively, has been analyzed and characterized in vitro in detail before (Kaiser et al., 2011, 2012; Ernst et al., 2015, 2017a). However, investigating single molecule interactions directly in cells has been a challenge due to detection limits of fluorescence microscopy. Here, by using PLA technology, which overcomes the detection limit in fluorescence microscopy for single molecule analysis by employing an internal amplification reaction, we demonstrate that $\mathrm{C} 2 \mathrm{I}$ is in close proximity to Hsp90, Cyp40, and FKBP51 in living cells, implicating an interaction between C2I and these host cell factors (Figures 1A-D). Every gray dot signal shown in Figure 1 represents an interaction event between C2I and Hsp90, Cyp40, or FKBP51, respectively. As control, cells were not treated with C2 toxin and although a background level of interaction signals was observed, the number of PLA signals significantly increased in the presence of $\mathrm{C} 2$ toxin, which was most obvious in the quantitative analysis. Moreover, the interaction between C2I and Hsp90, Cyp40, or FKBP51 was concentration-dependent (Figure 1F) and not only demonstrated in Vero cells (Figures 1A-C) but in a second and human cell line, i.e., HeLa (Figure 1D). Moreover, Hsp90, Cyp40, and FKBP51 were visualized in the same experiment by using fluorescence-labeled secondary antibodies. Figure 1E shows that a comparable signal was obtained in samples treated with $\mathrm{C}_{2}^{*}$ toxin and control samples for Hsp90, Cyp40, and FKBP51 indicating no effect of $\mathrm{C}^{*}$ toxin treatment on protein levels of these host cell factors. We further analyzed protein levels of Hsp90, Hsp70, FKBP51, and Cyp40 by Western blotting confirming that $\mathrm{C}^{*}$ toxin treatment showed no relevant effects on the protein levels after 1 and $24 \mathrm{~h}$ (Figure 2). Previously, we demonstrated that Hsp70 is also required for the membrane translocation of C2I into the host cell cytosol and moreover employed PLA to demonstrate the interaction of Hsp70 with C2I. Therefore, we also assessed the protein levels of Hsp70 after $\mathrm{C}^{*}$ toxin treatment in this experiment.

As indicated in Figure 1, the enzymatically inactive mutant C2IE387/389Q (Barth et al., 1998b) was used to perform the PLA assay. This mutant comprises two point mutations in the catalytic center of C2I preventing its ADP-RT activity and therefore cells treated with C2IIa plus C2IE387/389Q (referred to as C2*) do not round up. This constitutes a clear advantage for the analysis of fluorescence microscopic images because signals, in particular PLA signals, are distributed more evenly in a flatter cell body and therefore can be detected more easily. Moreover, cells treated with $\mathrm{C} 2^{*}$ show stronger adherence to culture dishes than cells treated with the wild type $\mathrm{C} 2$ toxin and therefore are more resistant against the multiple washing steps required for PLA analysis. Earlier, we described that enzymatic inactivation of C2I does not alter its uptake properties via C2IIa, which is a prerequisite to use C2IE387/389Q for PLA experiments (Hilger et al., 2009). Here, we confirmed this biological activity of C2IE387/389Q by performing a competition assay. Cells were treated with C2IIa plus C2I in the presence of two different concentrations of C2IE387/389Q. Results in Figures 3A,B show that the intoxication of cells with wild-type C2 is significantly delayed if C2IE387/389Q is present demonstrating that C2IE387/389Q competes with wild type C2I for binding to C2IIa and therefore confirms biological activity of C2IE387/389Q. Since cell rounding due to the C2I-catalyzed ADP-ribosylation of G-actin in cytosol of cultured cells represents a highly sensitive endpoint of toxin uptake, a lower concentration of $\mathrm{C} 2$ toxin compared to fluorescence microscopy experiments can be used in this experimental setup. Flow cytometry analysis shows that wild type C2I and C2IE387/389Q bind to cells via C2IIa, and no binding was detected of enzyme components alone (Figure 3D). Fluorescence microscopy demonstrates that wild type C2I and C2IE387/389Q were taken up into cells (Figure 3C), which was most obvious in cells that were still flat and did not round up yet. In rounded cells, indicated by the white arrow, the signal accumulates on a smaller area and is therefore difficult to analyze. Hence, $\mathrm{C}^{*}$ was used for PLA experiments. Moreover, we earlier demonstrated exemplarily that binding of wild-type C2I and C2IE387/389Q to Cyp40 is comparable confirming suitability of C2IE387/389Q for PLA analysis (Ernst et al., 2015).

\section{Combined Pharmacological Inhibition of Host Cell Factors Has Stronger Effect in Delaying Toxin-Induced Cell Morphology Than Inhibition of Each Factor Alone}

We demonstrated and characterized the protective effects of the single application of 1-50 $\mu \mathrm{M}$ radicicol [Rad, Hsp90 inhibitor (Pratt and Toft, 2003)], 10-20 $\mu \mathrm{M}$ cyclosporine A [CsA, Cyp inhibitor (Borel et al., 1976)], $20 \mu \mathrm{M}$ FK506 [FKBP inhibitor (Harding et al., 1989)], and $30 \mu \mathrm{M}$ VER [Hsp70 inhibitor (Williamson et al., 2009)] on cells in detail during the last years (Haug et al., 2003a, 2004; Kaiser et al., 2009, 2011, 2012; Ernst et al., 2015, 2016, 2017a). Combinations of two inhibitors, for example, the combination of $1 \mu \mathrm{M}$ Rad with $20 \mu \mathrm{M}$ CsA or $10 \mu \mathrm{M}$ CsA with $20 \mu \mathrm{M}$ FK506, have been tested and proven to result in a greater inhibition of intoxication with $\mathrm{C} 2$ toxin (Kaiser et al., 2009, 2011, 2012). However, a combination of all four inhibitors has not been tested so far. Here, we show that pharmacological inhibition of Hsp90, Hsp70, Cyps, and FKBPs results in a significantly stronger inhibition of intoxication of cells with C2 toxin compared to inhibition of single, two, or three host cell factors (Figure 4). This effect became most obvious after 

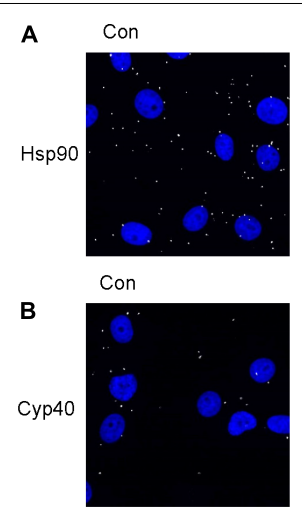

Con

C
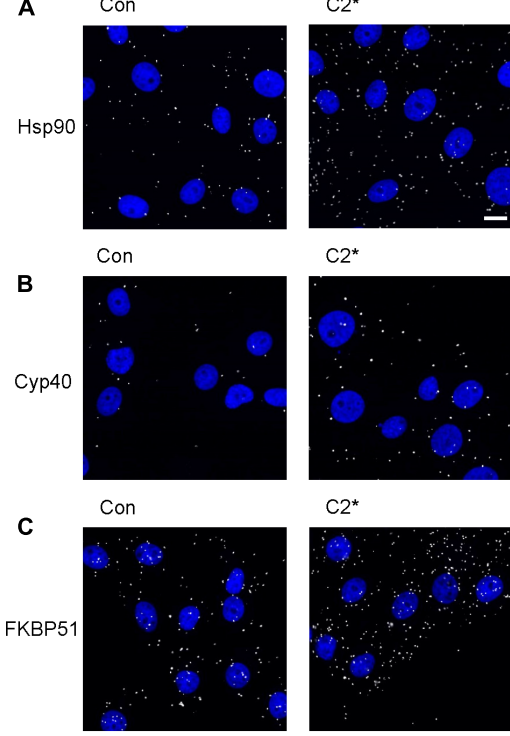

$\mathrm{C} 2^{*}$

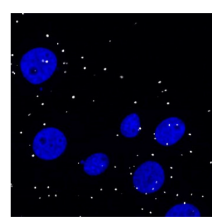

$\mathrm{C}^{*}$
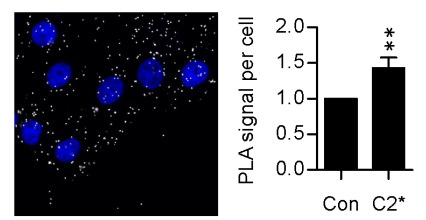

Con $\mathrm{C}^{*}$

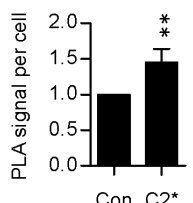

on $\mathrm{C}^{*}$

$\mathrm{C}^{*}$
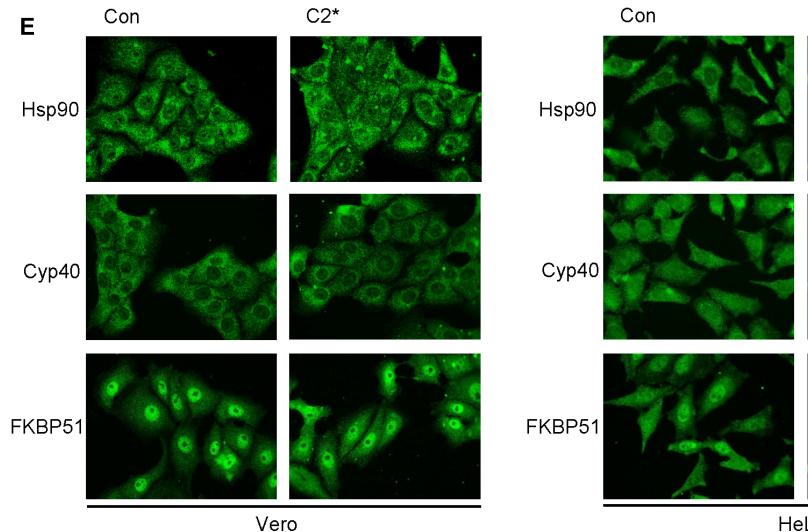

$\mathrm{C}^{*}$
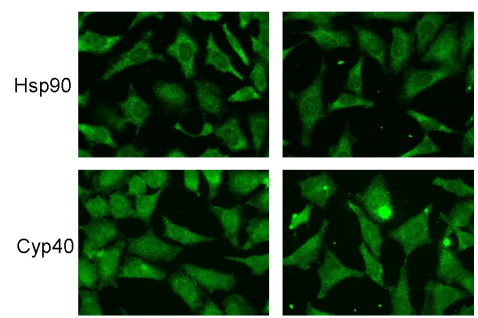

FKBP51
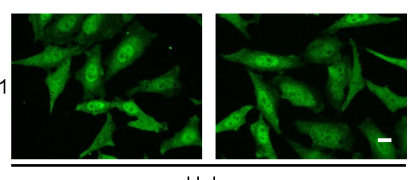
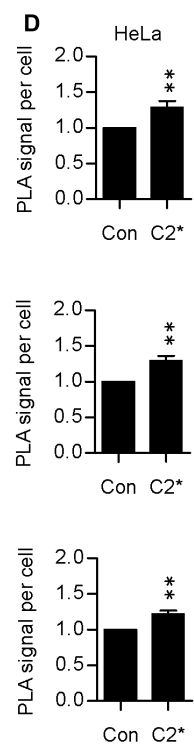

Con $\mathrm{C}^{*}$

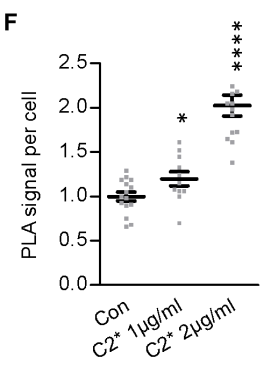

Hsp90

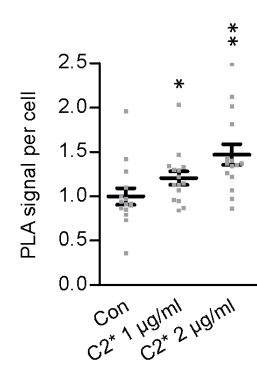

Cyp40

FIGURE 1 | Hsp90, Cyp40, and FKBP51 are in close proximity with C2I in the cytosol of Vero cells. Vero cells were incubated with C2* toxin [C2I E387/389Q plus C2lla, $1 \mu \mathrm{g} / \mathrm{ml}$ (B), or $2 \mu \mathrm{g} / \mathrm{ml}(\mathbf{A}, \mathbf{C})$ each] or left untreated for control for $1 \mathrm{~h}$ at $37^{\circ} \mathrm{C}$. Subsequently, cells were fixated with $4 \%$ PFA for $15 \mathrm{~min}$ and $100 \%$ methanol for 1 min, blocked with Sigma blocking solution, and treated with rabbit $\alpha$-C2IN (1:1500) and mouse $\alpha$-Hsp90 (1:8000) (A), mouse $\alpha$-Cyp40 (1:100) (B), or mouse $\alpha$-FKBP51 (1:100) (C). Then, the fluorescence-based PLA was performed according to the manufacturer's manual. The nucleus was stained with Hoechst. Images show overlay of PLA signal (gray) and nucleus (blue). Bar $=20 \mu \mathrm{m}$. The amount of PLA signals per cell was quantified by ImageJ. Values are normalized to control samples and are given as mean \pm SEM ( $n=5$ independent experiments, at least 200 cells per sample per experiment were analyzed). Significance was tested by using the Mann-Whitney test with GraphPad software (** $<$ 0.01). (D) HeLa cells were treated with C2* toxin (C2I E387/389Q plus C2lla, $1 \mu \mathrm{g} / \mathrm{ml}$ each) or left untreated for control for $1 \mathrm{~h}$ at $37^{\circ} \mathrm{C}$. Then, cells were treated as described in (A-C). (E) In addition to detecting PLA signals in samples (A-D), Hsp90, Cyp40, and FKBP51 were visualized with fluorescence-labeled secondary antibodies in the same samples. Bar $=20 \mu \mathrm{m}$. (F) The interaction of C2I with host cell factors is concentration-dependent. Vero cells were incubated with $\mathrm{C} 2^{*}$ toxin (C2I E387/389Q plus C2lla, 1 or $2 \mu \mathrm{g} / \mathrm{ml}$ each) or left untreated for control for $6 \mathrm{~h}$ at $37^{\circ} \mathrm{C}$ (Hsp90) or $1 \mathrm{~h}$ at $37^{\circ} \mathrm{C}$ (Cyp40, FKBP51). Subsequently, cells were treated as described above. Values are normalized to control samples and are given as mean \pm SEM ( $n=15$ images per condition, at least 200 cells per sample were analyzed). Significance was tested by using the Mann-Whitney test with GraphPad software and refers to the control $\left({ }^{*} p<0.1,{ }^{* *} p<0.01,{ }^{* * *} p<0.001,{ }^{* * * *} p<0.0001\right)$. 


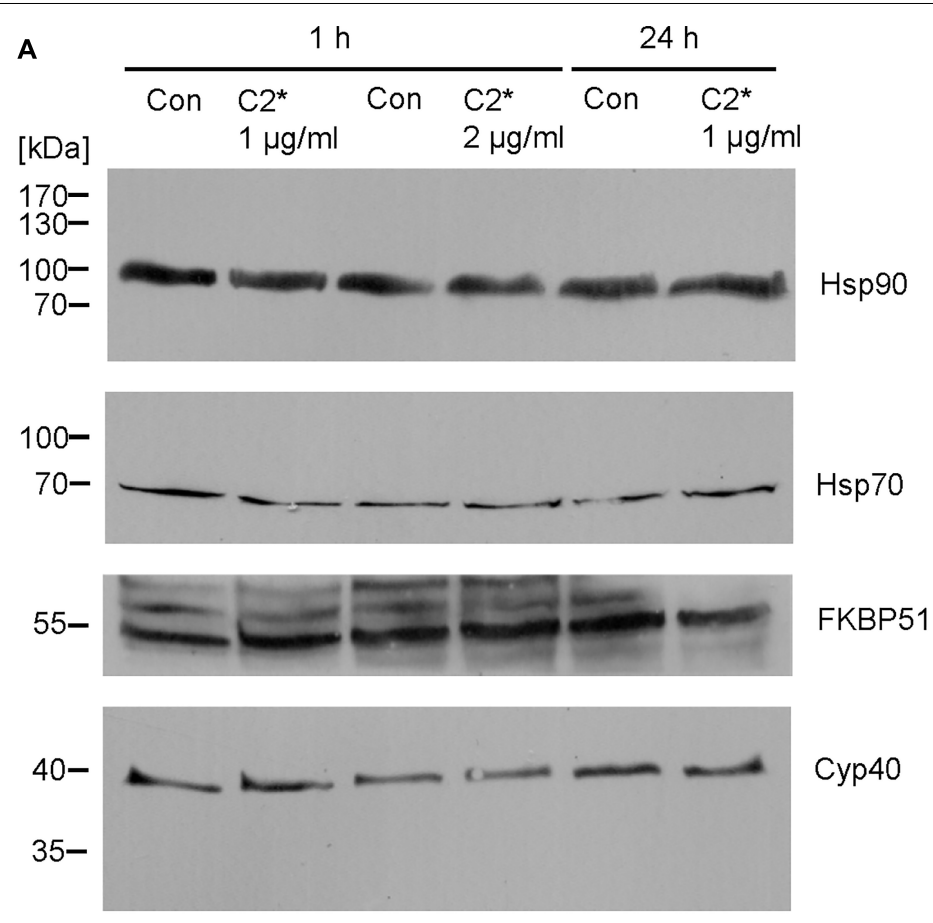

B

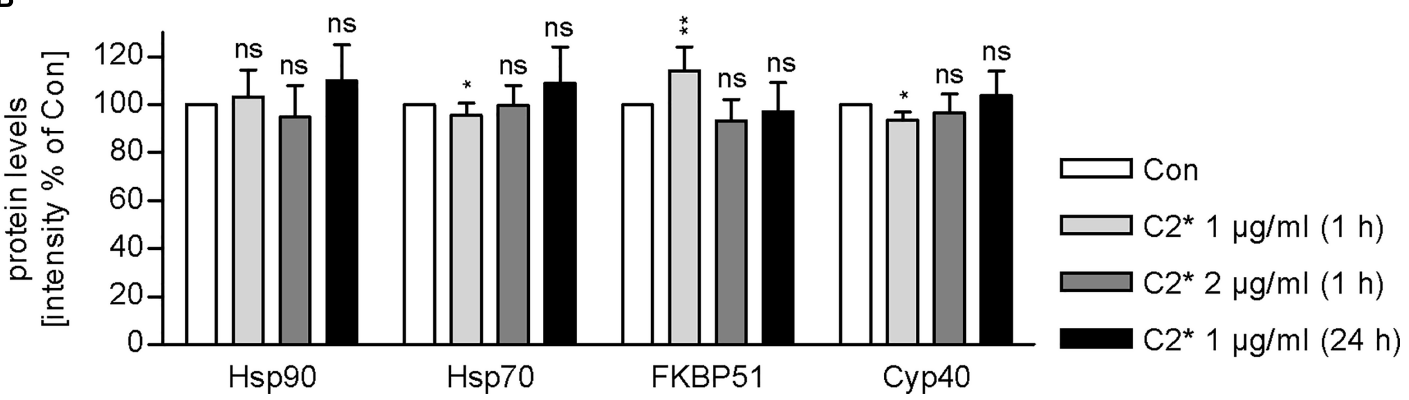

FIGURE 2 | Expression levels of host cell factors in cells after C2* treatment. Vero cells were incubated with C2* toxin (C2I E387/389Q plus C2lla, 1 or $2 \mu \mathrm{g} / \mathrm{ml}$, each) for indicated time points or left untreated for control. After washing, cells were lysed in Laemmli sample buffer and subjected to SDS-PAGE and Western blotting. Ponceau S staining confirmed successful transfer to nitrocellulose membrane (not shown). After blocking, the membrane was cut and probed with specific antibodies against Hsp90, Hsp70, FKBP51, and Cyp40, and signals were detected by horseradish peroxidase coupled secondary antibodies using the ECL system (A). (B) Intensity of Western blot signals was quantified by densitometry. Values are normalized to untreated control samples and are given as mean \pm SD $(n=3$ independent experiments). Significance was tested by using the student's $t$-test with GrapPad software and refers to control samples $\left({ }^{*} p<0.1\right.$, $* * p<0.01 ;$ ns, not significant).

longer incubation periods, i.e., 6 h. Notably, application of Rad, CsA, FK506, and VER in combination had no relevant effects on cell morphology after 6 and $24 \mathrm{~h}$ or cell viability after $24 \mathrm{~h}$ (Figures 4C,D).

\section{Combined Pharmacological Inhibition of Host Cell Chaperones/PPlases Prevents Membrane Translocation of C2I Into the Cytosol}

Results from previous studies concerning the effect of single application of chaperone/PPIase inhibitors suggest that the combination of Rad, CsA, FK506, and VER interferes with the membrane translocation of C2I from early endosomes into the cytosol of target cells. To elucidate which step of toxin uptake/mode of action is affected by the combined pharmacological inhibition of Hsp90, Hsp70, Cyps, and FKBPs, we analyzed the membrane translocation of $\mathrm{C} 2 \mathrm{I}$ in an isolated manner. Therefore, the membrane translocation step was mimicked directly at the cytoplasmic membrane to enable analysis of this step of toxin uptake in an isolated manner. To this end, cells were incubated on ice to minimize membrane fluidity and thus endocytosis. BafA1 is an inhibitor of the v-ATPase and was added to inhibit the "normal" uptake route 
A
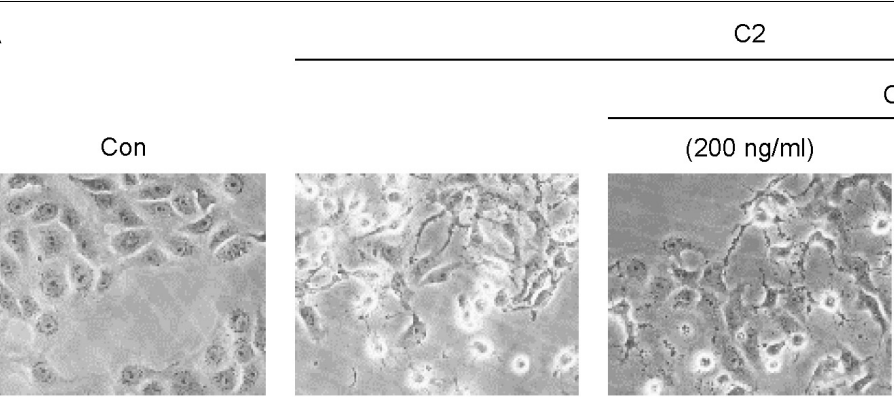

B

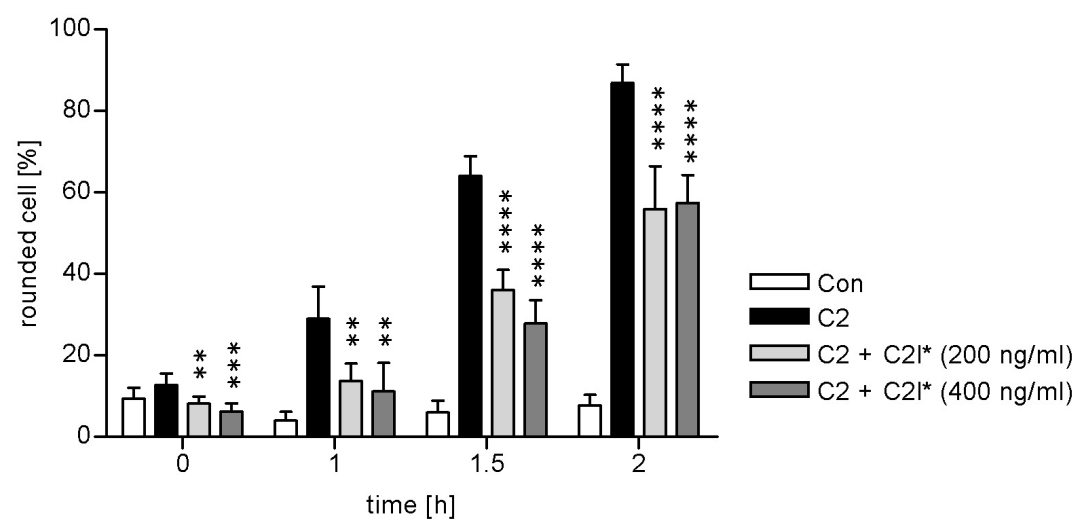

C

Con

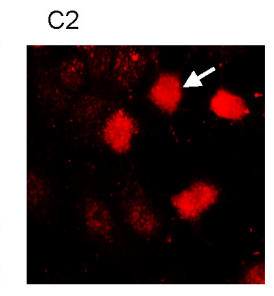

$\mathrm{C} 2 *$
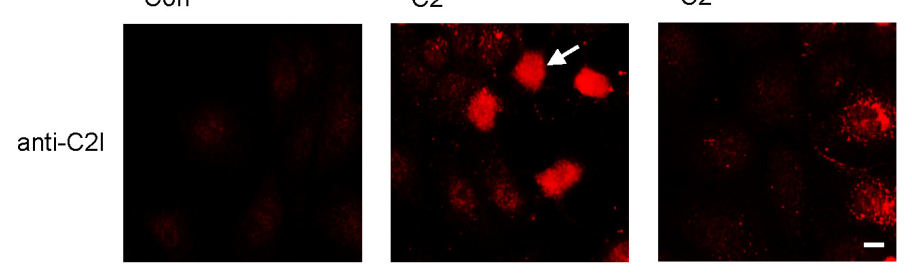

D

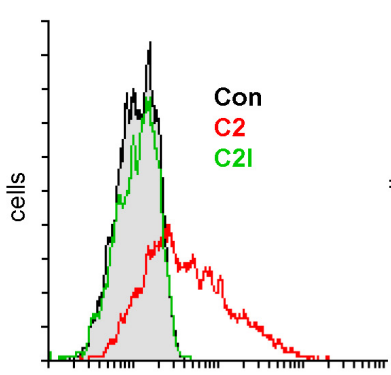

Log FL intensity

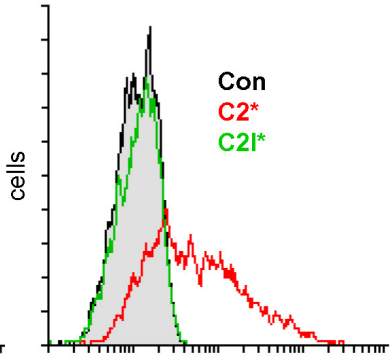

Log FL intensity

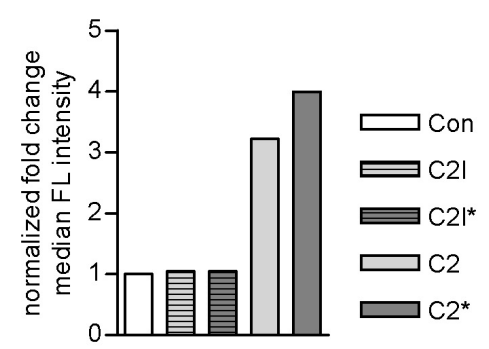

FIGURE 3 | C2I E387/389Q competes with wild type C2I for uptake via C2lla into cells. Vero cells were pre-incubated with C2 toxin (200 ng/ml C2I plus 400 ng/ml C2lla) and with or without C2I E387/389Q (C2/*) for 20 min on ice to allow binding to the membrane. Afterwards, cells were washed and incubated in toxin-free medium at $37^{\circ} \mathrm{C}$ to allow the toxin to enter the cell. (A) Representative pictures of cells $1.5 \mathrm{~h}$ after incubation at $37^{\circ} \mathrm{C}$. Bar $=25 \mu \mathrm{m}$. (B) Percentage of rounded cells was determined from pictures taken at the indicated time points. Values are given as mean \pm SD ( $n=6$ images from duplicates). The significance was tested with student's $t$-test by GraphPad software and values refer to samples treated with C2 alone $\left(* * p<0.01,{ }^{* * *} p<0.001\right.$, $\left.{ }^{* * * *} p<0.0001\right)$. (C) Vero cells were incubated with wildtype C2 or mutant C2* $(0.5 \mu \mathrm{g} / \mathrm{ml} \mathrm{C2l}$ or C2I E387/389Q, respectively, plus $1 \mu \mathrm{g} / \mathrm{ml}$ C2lla) for $1 \mathrm{~h}$. Cells were washed with PBS, fixed, permeabilized, and blocked with FCS. C2I or C2I E387/389Q were detected by a specific antiserum and fluorescence labeled secondary antibody. Bar = $10 \mu \mathrm{m}$. White arrow indicates rounded cell due to C2I enzyme activity. (D) C2 and C2* toxin bind to Vero cells. Vero cell suspensions (200,000 cells in 0.2 ml MEM containing serum) were incubated on ice for 10 min with DyLight488-labeled $0.6 \mu \mathrm{g} / \mathrm{ml} \mathrm{C2I} \mathrm{or} \mathrm{C2I} \mathrm{E387/389Q} \mathrm{(indicated} \mathrm{as} \mathrm{C2/*)} \mathrm{with} \mathrm{or} \mathrm{without} 1.5 \mu \mathrm{g} / \mathrm{ml}$ C2Ila. After washing with PBS, cells were resuspended in medium and subjected to flow cytometry analysis. Results are presented as overlay histograms, where single cell events (cells) are plotted against the intensity of cell surface-bound fluorescence (Log FL intensity). Gray peak (identical in both overlays) represents the background fluorescence of mock-treated cells. The bar graph shows the fold change of the median fluorescence (FL) intensity of histogram peaks. Values are normalized to control. Results from one representative experiment are shown. 
A

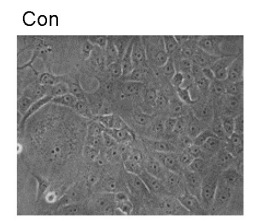

CsA+Rad+FK506+VER
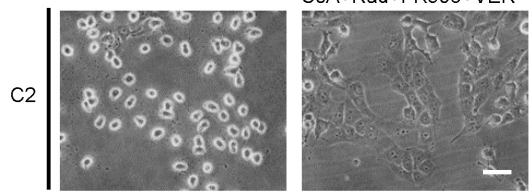

B

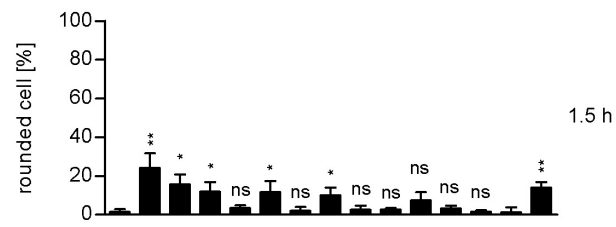

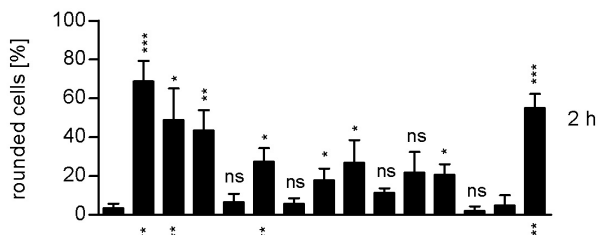

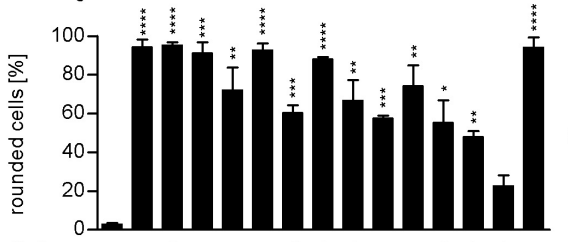
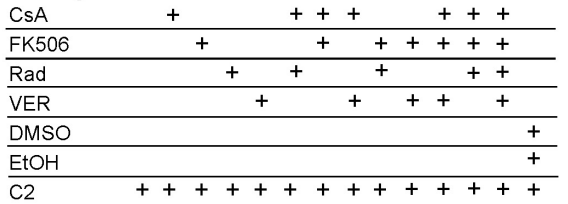

C
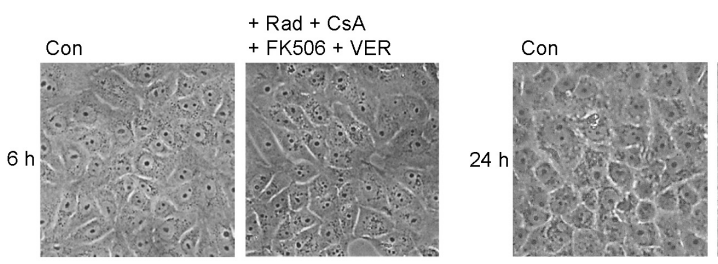

$+\operatorname{Rad}+\operatorname{CsA}$

+ FK506 + VER

D

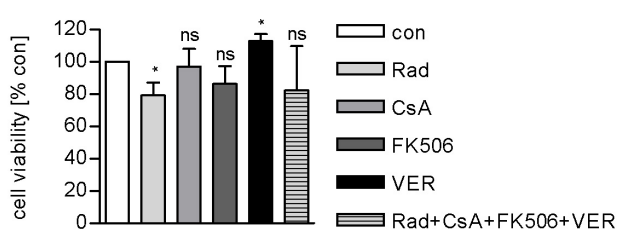

FIGURE 4 | Combined inhibition of host cell factors delays toxin-induced cell morphology. Vero cells were pre-incubated with CsA (20 $\mu$ M), FK506 (30 $\mu$ M), Rad $(20 \mu \mathrm{M})$, and VER $(30 \mu \mathrm{M})$ alone or in combinations for $30 \mathrm{~min}$ at $37^{\circ} \mathrm{C}$ and then intoxicated with $\mathrm{C} 2$ toxin $(25 \mathrm{ng} / \mathrm{ml} \mathrm{C} 21 \mathrm{plus} 50 \mathrm{ng} / \mathrm{ml} \mathrm{C} 21 \mathrm{la})$ and incubated at $37^{\circ} \mathrm{C}$. For control, cells were left untreated, treated with $\mathrm{C} 2$ toxin only or treated with solvents of inhibitors (DMSO $+\mathrm{EtOH})$ and $\mathrm{C} 2$ toxin. (A) Pictures show the morphological changes of cells $6 \mathrm{~h}$ after toxin treatment. Con, untreated cells. Bar $=50 \mu \mathrm{m}$. (B) Percentage of rounded cells was determined from images at indicated time points. Values are given as mean $\pm \mathrm{SD}(n=3)$. Significance was tested with Student's $t$-test by GraphPad software and values refer to samples treated with C2 toxin plus combination of Rad, CsA, FK506, and VER for each time point (ns, not significant; ${ }^{*} p<0.1,{ }^{* *} p<0.01,{ }^{* * *} p<0.001,{ }^{* * * *} p<0.0001$ ). (C) Vero cells were incubated with a combination of Rad, CsA, FK506, and VER or left untreated for control. Pictures were taken after 6 and $24 \mathrm{~h}$. Bar $=50 \mu \mathrm{m}$. (D) Vero cells were incubated with a combination of Rad, CsA, FK506, and VER or left untreated for control. After $24 \mathrm{~h}$, cell viability was measured by adding MTS reagent for $1 \mathrm{~h}$ at $37^{\circ} \mathrm{C}$ and resulting formazan was measured at $490 \mathrm{~nm}$. Values are given as mean $\pm \mathrm{SD}$ and are normalized to untreated control $(n=3$ independent experiments). Significance was tested by using the student's $t$-test with GraphPad software and refers to control samples $\left({ }^{*} p<0.1 ;\right.$ ns, not significant). 
of C2I over acidified endosomes (Sandvig and Olsnes, 1980; Bowman et al., 1988). After binding of C2 toxin to the cooled cells, warm acidic medium was added to mimic acidic conditions in endosomes and thus enable pore formation by C2IIa and translocation of C2I directly through the cytoplasmic membrane into the cytosol of cells. Rounding of adherent cells was employed as a specific endpoint of toxin uptake in this assay. In this assay too, the combination of Rad, CsA, FK506, and VER revealed a stronger inhibitory effect than application of the single substances and efficiently protected cells from intoxication with $\mathrm{C} 2$ toxin (Figure 5). Importantly, the combination of Rad, CsA, FK506, and VER did not significantly inhibit other steps of toxin uptake or C2I enzyme activity (Figures 5B,C). This result confirms that combined inhibition of Hsp90, Hsp70, Cyps, and FKBPs interferes with the membrane translocation of C2I from early endosomes into the cytosol of target cells.

Taken all together, we showed that Hsp90, Cyp40, and FKBP51 are located in close proximity with C2I in Vero and HeLa cells and therefore most likely interact in the cytosol of target cells. This interaction was concentrationdependent. Protein levels of Hsp90, Hsp70, FKBP51, and Cyp40 were not affected by $\mathrm{C} 2{ }^{*}$ toxin treatment. Moreover, we demonstrated that the combination of specific pharmacological inhibitors of chaperone/PPIase activities protected target cells from intoxication with $\mathrm{C} 2$ toxin and interfered with membrane translocation of C2I from endosomes into the cytosol but not with cell binding or enzyme activity. Interestingly, the effects of the combination of Hsp90, Hsp70, Cyp, and FKBP activity inhibition were significantly stronger than the effects of a single inhibitor treatment and combining Rad, CsA, FK506, and VER had no significant effects on cell viability after $24 \mathrm{~h}$. This finding might be of interest regarding the development of novel pharmacological strategies against diseases caused by toxinproducing bacteria.

\section{DISCUSSION}

Bacterial AB-type protein toxins are the causative agents for various severe diseases, such as diphtheria, whooping cough, cholera, and further enteric diseases. Although several of the toxin-induced diseases have been known for a long time and therapeutic or vaccination strategies are available, these diseases pose a severe threat to human and also livestock health and survival. The enterotoxin C. botulinum $\mathrm{C} 2$ toxin consists of two components: C2I harboring ADP-ribosyltransferase activity and C2IIa facilitating receptor-binding, uptake, and translocation of C2I into the cytosol of target cells. Here, C2I covalently transfers an ADP-ribose moiety onto G-actin leading to depolymerization of F-actin and therefore to rounding up of adherent cells. C2 has been shown to display severe enterotoxicity in various animal models (Barth and Ernst, 2016; Stiles, 2017). A necessity for C2 toxin to exert this enterotoxicity is to reach the cytosol of target cells since there its substrate G-actin is localized. C2 toxin employs a very elaborate uptake mechanism during, which cellular protein trafficking mechanisms are exploited, i.e., receptor-binding or receptor-mediated endocytosis. A particularly crucial step of toxin uptake is the membrane translocation from endosomal compartments to the cytosol. The physiologically acidification of the endosomal lumen leads to conformational changes in both components of C2 toxin (Barth et al., 2000; Haug et al., 2003b). The C2IIa heptamer forms a pore into the endosomal membrane and C2I is at least partially unfolded to translocate through the narrow C2IIa pores into the cytosol. During the last years, we discovered that the $\mathrm{C} 2$ toxin exploits further cellular mechanisms for successfully reaching the cytosol: C2I interacts with host cell chaperones and PPIases, which facilitate its translocation and most likely its refolding into a native and therefore enzymatically active conformation (Barth and Ernst, 2016; Ernst et al., 2017b). This suggests that the chaperones and PPIases should represent attractive novel drug targets in the context of diseases that are caused by such bacterial protein toxins. Indeed, inhibition of the activity of Hsp90, Hsp70, Cyps, and FKBPs by specific pharmacological inhibitors protected cells from intoxication with $\mathrm{C} 2$ toxin and specifically inhibited the membrane translocation of C2I into the cytosol. These findings harbor medical implications because if C2I cannot reach the cytosol G-actin cannot be modified and clinical symptoms can be prevented.

Here, we show that C2I is in close proximity and therefore most likely interacting with Hsp90, Cyp40, and FKBP51 in cells indicating their importance for successful toxin uptake into the cell. In vitro, this interaction has been demonstrated and characterized in detail before. Hsp90, Cyp40, and FKBP51 coprecipitated with C2I from toxin-treated cells (Kaiser et al., 2012; Ernst et al., 2015). A direct interaction between Hsp90, Cyp40, FKBP51, and C2I was demonstrated using dot blot analysis (Kaiser et al., 2011, 2012; Ernst et al., 2015, 2016, 2017a). Moreover, we exemplarily determined the dissociation constant of the C2I-Cyp40 interaction using isothermal titration calorimetry to be in the nanomolar range $\left(K_{\mathrm{D}}=101 \mathrm{nM}\right)$ (Ernst et al., 2015). Analysis of an interaction in cells harbors difficulties since the detection of single molecule interaction by fluorescence microscopy challenges its detection limit. In our previous work, we established a novel assay, the PLA, and thereby demonstrated the interaction between Hsp70 and C2I in cells (Ernst et al., 2017a). This assay allows the detection of two molecules in close proximity via fluorescence microscopy by employing an internal signal amplification reaction that is polymerase-based (Söderberg et al., 2008). Here, this PLA method was used to show that also Hsp90, Cyp40, and FKBP51 were in close proximity i.e., interacted with C2I in C2-treated cells. This further confirms the important role these host cell factors play during toxin uptake.

The activity of Hsp90, Hsp70, Cyps, and FKBPs can be prevented by specific pharmacological inhibitors. Rad binds to the ATP-binding pocket of Hsp90 thereby inhibiting its activity in cells (Pratt and Toft, 2003; Li and Buchner, 2013). The same mechanism holds true for inhibition of Hsp70 by VER (Williamson et al., 2009). CsA and FK506 interfere with PPIase activity of Cyps and FKBPs, respectively (Handschumacher et al., 1984; Fischer et al., 1989; Harding et al., 1989; Galat, 2003). 
A

C2

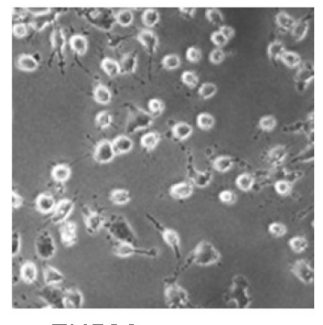

+ FK506

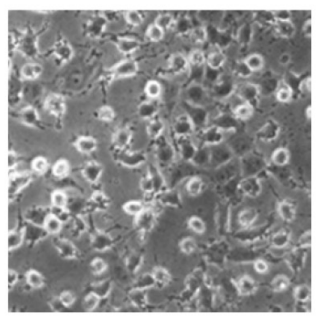

$+\mathrm{Rad}+\mathrm{CsA}$

+ FK506 + VER

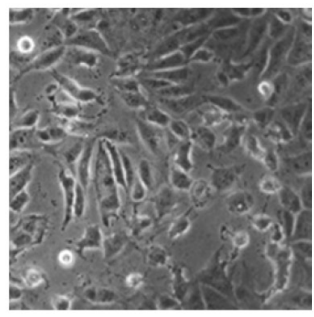

$+\operatorname{Rad}$

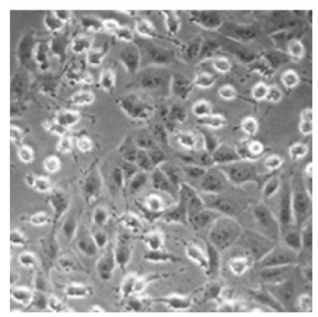

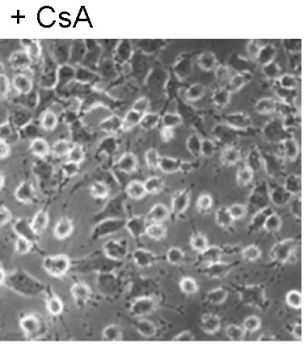

+ VER

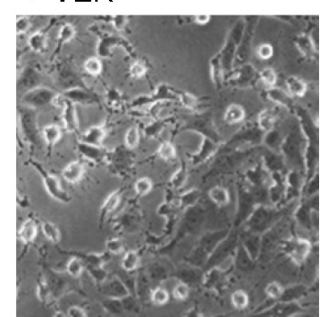

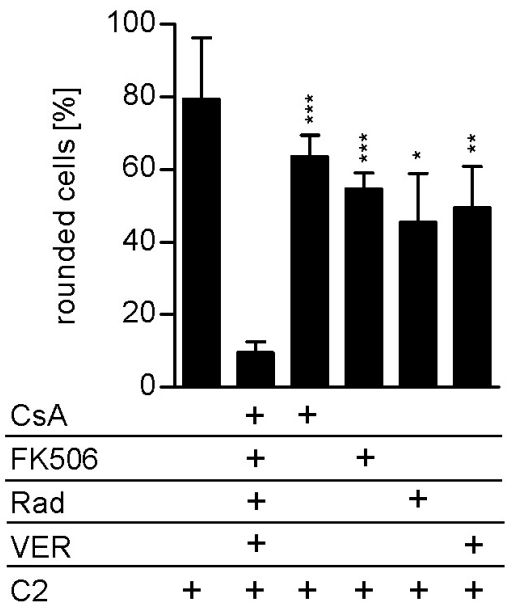

B

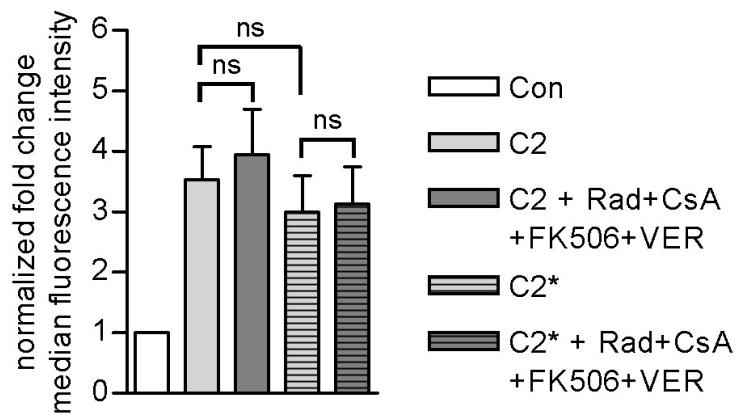

C

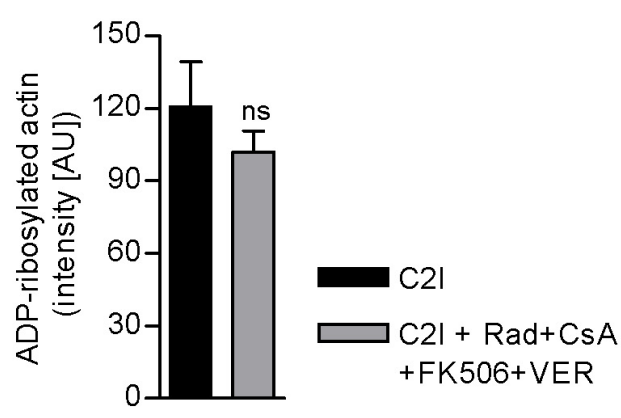

FIGURE 5 | (A) Combined inhibition of host cell chaperones/PPlases prevents membrane translocation of C2I into cytosol. Vero cells were pre-incubated with CsA $(20 \mu \mathrm{M})$, FK506 $(30 \mu \mathrm{M})$, Rad $(20 \mu \mathrm{M})$, and VER $(30 \mu \mathrm{M})$ alone or in combination for 30 min at $37^{\circ} \mathrm{C}$ in BafA1-containing medium. As control, cells were treated with BafA1-containing medium only. Cells were cooled to $4^{\circ} \mathrm{C}$, and $\mathrm{C} 2$ toxin was added on ice for 20 min. Then, cells were challenged with warm acidic medium for 5 min at $37^{\circ} \mathrm{C}$. For control, cells were treated with neutral medium (not shown). Medium was exchanged to fresh pH neutral medium containing BafA1 and respective inhibitors and cells were further incubated for $2.5 \mathrm{~h}$. Toxin-induced morphological changes were monitored. Bar $=50 \mu \mathrm{m}$. Percentage of rounded cells was determined from pictures. Values are given as mean $\pm \mathrm{SD}(n=3$ pictures per sample). Results from one representative experiment are shown. Significance was tested with Student's t-test by GraphPad software and values refer to samples treated with C2 toxin plus combination of Rad, CsA, FK506, and VER (ns, not significant; $\left.{ }^{*} p<0.1,{ }^{* *} p<0.01,{ }^{* * *} p<0.001\right)$. (B) Effect of the combination of Rad, CsA, FK506, and VER on the binding of C2 or C2* toxin to Vero cells. Vero cell suspensions ( 200,000 cells in $0.2 \mathrm{ml} \mathrm{MEM} \mathrm{containing} \mathrm{serum)} \mathrm{were} \mathrm{incubated} \mathrm{with} \mathrm{CsA} \mathrm{(20} \mu \mathrm{M})$, FK506 (30 $\mu \mathrm{M})$, Rad (20 $\mu \mathrm{M})$, and VER (30 $\mu \mathrm{M})$ or left untreated for $30 \mathrm{~min}$ at $37^{\circ} \mathrm{C}$. Subsequently, cells were incubated on ice for $5 \mathrm{~min}$ and then further incubated with DyLight488-labeled 0.6 $\mu \mathrm{g} / \mathrm{ml} \mathrm{C} 2 \mathrm{l}$ or C2I E387/389Q (C2/*) plus $1.5 \mu \mathrm{g} / \mathrm{ml}$ C2lla for $10 \mathrm{~min}$ on ice. After washing with PBS, cells were resuspended in medium and subjected to flow cytometry analysis. The median FL intensity was calculated from histograms. Shown is the fold change of the median FL intensity normalized to control ( $n=6$ values from two independent experiments). Values are given as mean \pm SD. Significance was tested with Student's $t$-test by GraphPad software (ns, not significant). (C) Effect of the combination of Rad, CsA, FK506, and VER on the enzyme activity of C2I in vitro. Vero cell lysate (20 $\mu \mathrm{g})$ was pre-incubated with CsA (20 $\mu \mathrm{M})$, FK506 (30 $\mu \mathrm{M})$, Rad (20 $\mu \mathrm{M})$, and VER $(30 \mu \mathrm{M})$ or left untreated for $30 \mathrm{~min}$ at $37^{\circ} \mathrm{C}$. C2l $(200 \mathrm{ng})$ and biotin-NAD ${ }^{+}$were added for 20 min at $37^{\circ} \mathrm{C}$. Biotin-labeled i.e., ADP-ribosylated actin was detected via streptavidin-coupled horseradish peroxidase using the ECL system. Intensity of Western blot signals was quantified by densitometry. Values are given as mean $\pm \mathrm{SD}(n=4)$. Results from one representative experiment are shown. Significance was tested by using the student's $t$-test with GraphPad (ns, not significant).

Previously, we demonstrated that Rad, VER, CsA, and FK506 protect cells from intoxication of $\mathrm{C} 2$ toxin and combinations of two inhibitors resulted in stronger protection of cells compared to application of single substances (Haug et al., 2003a; Kaiser et al., 2009, 2012; Ernst et al., 2015, 2017a). The present study reveals that a combination of Rad, VER, CsA, and FK506 has an even stronger inhibitory effect than the single inhibitors or combinations of two on intoxication and in particular membrane translocation of C2I to the cytosol. One could speculate that the molecular mechanisms underlying the observed stronger protection of cells by a combination of Hsp90, Hsp70, Cyp, and FKBP inhibition compared to an application of the single substances may arise from the fact that targeted folding helper proteins with similar functions in supporting/promoting protein 
folding are able to functionally replace each other in cells. Thus combination of the different drugs could circumvent partial or even nearly complete rescue by the folding helper proteins still in function. It might be that the pharmacological inhibition of one folding helper enzyme generates conditions in the cells, under which the presence of one or more of the other folding helpers are required to maintain cellular life. In case of a steroid receptor complex like scenario, the stronger effects of combined inhibition may also result from functional replacement. There, it could also be that only the complete inhibition of such a complex occurs, if all the components of the complex are inhibited and that incomplete complexes are functional, but in a diminished manner or not with their full efficiency.

At the same time, the combination of inhibitors alone had no adverse effects on the morphology of cells. Rad and derivatives have been tested in anti-tumor treatment, revealing, however, some adverse effects that require the search and development for novel well-tolerated derivative (Li and Buchner, 2013). CsA and FK506 are approved immunosuppressive drugs applied mostly after organ transplantation to prevent organ rejection (Borel et al., 1976; Liu et al., 1991; Schreiber et al., 1991). Interaction of CsA or FK506 with Cyps or FKBPs, respectively, allows the inhibitor-protein complex to interact with a protein phosphatase in cells, calcineurin. This leads to inhibition of calcineurin and therefore the transcription factor nuclear factor of activated T-cells (NF-AT) cannot be dephosphorylated by calcineurin resulting in decreased activation of T-lymphocytes (Liu et al., 1991; Schreiber et al., 1991; Clipstone and Crabtree, 1992). Although this mode of action is necessary to use CsA/FK506 as immunosuppressant, in the context of a bacterial infection administration of an immunosuppressive drug is highly counterproductive. In 2015, we demonstrated that a CsA derivative, VK112, which lacks the immunosuppressive effect but still inhibits PPIase activity of Cyps, protects cells from intoxication with the clostridial C2, iota, and CDT toxin (Prell et al., 2013; Ernst et al., 2015), and we further extended these findings for the diphtheria toxin (Schuster et al., 2017) and pertussis toxin (Ernst et al., 2018). Therefore, the development and engineering of pharmacological inhibitors are highly demanded and represent a promising opportunity to discover novel therapeutic strategies against diseases caused by bacterial protein toxins.

This is of special importance since the current treatment options for several toxin-caused diseases are limited. For example, there is no causative treatment available against the severe childhood disease whooping cough, caused by pertussis toxin produced by Bordetella pertussis, which can be lifethreatening especially to newborns that cannot be vaccinated yet (Mattoo and Cherry, 2005; Carbonetti, 2015; World Health Organization [WHO], 2016). Moreover, C. difficile infections pose a severe threat especially to hospitalized patient undergoing antibiotic therapy (Aktories et al., 2018; Papatheodorou et al., 2018). Case numbers are still increasing every year in Western countries and hypervirulent strains are emerging. The two ABtype toxins $\mathrm{A}$ and $\mathrm{B}$ of $\mathrm{C}$. difficile cause severe symptoms such as antibiotic-associated diarrhea and pseudomembranous colitis (Aktories et al., 2017a). Hypervirulent C. difficile strains produce a third toxin, CDT, additionally to toxins $\mathrm{A}$ and $\mathrm{B}$, which belongs to the ADP-ribosylating toxins. CDT increases the adherence of $C$. difficile in the gut by forming long protrusions in which the bacteria get caught. For these strains, an increased reoccurrence of the infection has been reported, increasing the risk for developing lifethreatening complications, and a prolonged suffering for the patient (Aktories et al., 2018). Up to now, CDI is treated with specific antibiotics and an antibody against toxin $B$ is available. However, antibodies or antitoxins can only eliminate toxin molecules that did not bind to cells or have been internalized yet. Therefore, novel therapeutic strategies i.e., targeting chaperones/PPIases that act intracellular might be a valuable asset to improve and support current treatment strategies to prevent severe courses of disease and reoccurrence of CDI.

During our investigations over the last years, we observed that all toxins we investigated so far which harbor an ADPribosyltransferase activity require chaperones and PPIases for their membrane translocation regardless of their structure, composition, or uptake route into the cell (Ernst et al., 2017b). This group of toxins comprises the clostridial binary toxins, diphtheria toxin, pertussis toxin, cholera toxin, and the large insecticidal toxins PTC3 and PTC5 (Haug et al., 2003a, 2004; Kaiser et al., 2009, 2011, 2012; Burress et al., 2014; Lang et al., 2014; Ernst et al., 2015, 2016, 2017a, 2018; Schuster et al., 2017). Toxins displaying a different enzyme activity such as the $C$. difficile glucosylating toxins or Bacillus anthracis lethal toxin are independent of these host cell factors (Haug et al., 2003a; Kaiser et al., 2009, 2011; Zornetta et al., 2010; Dmochewitz et al., 2011). The uptake of toxin constructs artificially containing an ADP-ribosyltransferase activity or isolated ADP-ribosyltransferase domains relies on the activity of Hsp90, Hsp70, Cyps, and FKBPs (Haug et al., 2003a; Dmochewitz et al., 2011; Lang et al., 2014; Ernst et al., 2017a). This implicates that novel therapeutic strategies developed on the basis of these chaperones/PPIases might not only be used to treat one disease, but all diseases caused by the same group of bacterial toxins, namely the ADP-ribosylating toxins.

\section{AUTHOR CONTRIBUTIONS}

KE designed, supervised and conducted the experiments and wrote the manuscript. $\mathrm{CK}$ and $\mathrm{ML}$ conducted the experiments. HB designed and supervised the study and wrote the manuscript.

\section{FUNDING}

This work was financially supported by the Deutsche Forschungsgemeinschaft (Grant No. BA2087/2-2 to HB) and by the Medical Faculty Ulm (Baustein 3.2 to KE). 


\section{ACKNOWLEDGMENTS}

ML is a member of the International Graduate School in Molecular Medicine Ulm (IGradU, Research Program Experimental Medicine) and thanks IGradU for the support. Ina

\section{REFERENCES}

Aktories, K., Bärmann, M., Ohishi, I., Tsuyama, S., Jakobs, K. H., and Habermann, E. (1986). Botulinum C2 toxin ADP-ribosylates actin. Nature 322, 390-392. doi: 10.1038/322390a0

Aktories, K., Papatheodorou, P., and Schwan, C. (2018). ). Binary Clostridium difficile toxin (CDT) - A virulence factor disturbing the cytoskeleton. Anaerobe doi: 10.1016/j.anaerobe.2018.03.001 [Epub ahead of print].

Aktories, K., Schwan, C., and Jank, T. (2017a). Clostridium difficile toxin biology. Annu. Rev. Microbiol. 71, 281-307. doi: 10.1146/annurev-micro-090816093458

Aktories, K., Schwan, C., and Lang, A. E. (2017b). ADP-Ribosylation and crosslinking of actin by bacterial protein toxins. Handb. Exp. Pharmacol. 235, 179-206. doi: 10.1007/164-2016-26

Aktories, K., and Wegner, A. (1992). Mechanisms of the cytopathic action of actinADP-ribosylating toxins. Mol. Microbiol. 6, 2905-2908. doi: 10.1111/j.13652958.1992.tb01749.x

Barth, H., and Aktories, K. (2011). New insights into the mode of action of the actin ADP-ribosylating virulence factors Salmonella enterica SpvB and Clostridium botulinum C2 toxin. Eur. J. Cell Biol. 90, 944-950. doi: 10.1016/j.ejcb.2010.11. 007

Barth, H., Blocker, D., Behlke, J., Bergsma-Schutter, W., Brisson, A., Benz, R., et al. (2000). Cellular uptake of Clostridium botulinum C2 toxin requires oligomerization and acidification. J. Biol. Chem. 275, 18704-18711. doi: $10.1074 /$ jbc.M000596200

Barth, H., and Ernst, K. (2016). "Chaperones and ADP-ribosylating bacterial toxins," in Microbial Toxins Toxinology, eds P. Gopalakrishnakone, B. Stiles, A. Alape-Girón, J. D. Dubreuil, and M. Mandal (Dordrecht: Springer).

Barth, H., Hofmann, F., Olenik, C., Just, I., and Aktories, K. (1998a). The $\mathrm{N}$-terminal part of the enzyme component (C2I) of the binary Clostridium botulinum $\mathrm{C} 2$ toxin interacts with the binding component $\mathrm{C} 2 \mathrm{II}$ and functions as a carrier system for a Rho ADP-Ribosylating C3-like fusion toxin. Infect. Immun. 66, 1364-1369.

Barth, H., Preiss, J. C., Hofmann, F., and Aktories, K. (1998b). Characterization of the catalytic site of the ADP-ribosyltransferase Clostridium botulinum C2 toxin by site-directed mutagenesis. J. Biol. Chem. 273, 29506-29511.

Billington, S. J., Wieckowski, E. U., Sarker, M. R., Bueschel, D., Songer, J. G., and McClane, B. A. (1998). Clostridium perfringens Type E animal enteritis isolates with highly conserved, silent enterotoxin gene sequences. Infect. Immun. 66, 4531-4536.

Blöcker, D., Barth, H., Maier, E., Benz, R., Barbieri, J. T., and Aktories, K. (2000). The C terminus of component C2II of Clostridium botulinum C2 toxin is essential for receptor binding. Infect. Immun. 68, 4566-4573. doi: 10.1128/IAI. 68.8.4566-4573.2000

Borel, J. F., Feurer, C., Gubler, H. U., and Stähelin, H. (1976). Biological effects of cyclosporin A: a new antilymphocytic agent. Agents Actions 6, 468-475. doi: 10.1007/BF01973261

Bowman, E. J., Siebers, A., and Altendorf, K. (1988). Bafilomycins: a class of inhibitors of membrane ATPases from microorganisms, animal cells, and plant cells. Proc. Natl. Acad. Sci. U.S.A. 85, 7972-7976. doi: 10.1073/pnas.85.21.7972

Brandts, J. F., Halvorson, H. R., and Brennan, M. (1975). Consideration of the possibility that the slow step in protein denaturation reactions is due to cistrans isomerism of proline residues. Biochemistry 14, 4953-4963. doi: 10.1021/ bi00693a026

Burress, H., Taylor, M., Banerjee, T., Tatulian, S. A., and Teter, K. (2014). Co- and post-translocation roles for HSP90 in cholera intoxication. J. Biol. Chem. 289, 33644-33654. doi: 10.1074/jbc.M114.609800

Carbonetti, N. H. (2015). Contribution of pertussis toxin to the pathogenesis of pertussis disease. Pathog. Dis. 73:ftv073. doi: 10.1093/femspd/ftv073
Felix and Panagiotis Papatheodorou are thanked for providing materials and for introduction into flow cytometry protocols. Anna Anastasia is thanked for excellent technical assistance. Cordelia Schiene-Fischer and Gunter Fischer are thanked for fruitful cooperation and discussions.

Chacinska, A., Koehler, C. M., Milenkovic, D., Lithgow, T., and Pfanner, N. (2009). Importing mitochondrial proteins: machineries and mechanisms. Cell 138, 628-644. doi: 10.1016/j.cell.2009.08.005

Clerico, E. M., Tilitsky, J. M., Meng, W., and Gierasch, L. M. (2015). How hsp70 molecular machines interact with their substrates to mediate diverse physiological functions. J. Mol. Biol. 427, 1575-1588. doi: 10.1016/j.jmb.2015. 02.004

Clipstone, N. A., and Crabtree, G. R. (1992). Identification of calcineurin as a key signalling enzyme in T-lymphocyte activation. Nature 357, 695-697. doi: $10.1038 / 357695 \mathrm{a} 0$

Dmochewitz, L., Lillich, M., Kaiser, E., Jennings, L. D., Lang, A. E., Buchner, J., et al. (2011). Role of CypA and Hsp90 in membrane translocation mediated by anthrax protective antigen. Cell. Microbiol. 13, 359-373. doi: 10.1111/j.14625822.2010.01539.x

Eckhardt, M., Barth, H., Blöcker, D., and Aktories, K. (2000). Binding of Clostridium botulinum C2 toxin to asparagine-linked complex and hybrid carbohydrates. J. Biol. Chem. 275, 2328-2334. doi: 10.1074/jbc.275.4.2328

Ernst, K., Eberhardt, N., Mittler, A.-K., Sonnabend, M., Anastasia, A., Freisinger, S., et al. (2018). Pharmacological cyclophilin inhibitors prevent intoxication of mammalian cells with Bordetella pertussis toxin. Toxins 10:E181. doi: 10.3390/ toxins 10050181

Ernst, K., Langer, S., Kaiser, E., Osseforth, C., Michaelis, J., Popoff, M. R., et al. (2015). Cyclophilin-facilitated membrane translocation as pharmacological target to prevent intoxication of mammalian cells by binary clostridial actin ADP-ribosylated toxins. J. Mol. Biol. 427, 1224-1238. doi: 10.1016/j.jmb.2014. 07.013

Ernst, K., Liebscher, M., Mathea, S., Granzhan, A., Schmid, J., Popoff, M. R., et al. (2016). A novel Hsp70 inhibitor prevents cell intoxication with the actin ADPribosylating Clostridium perfringens iota toxin. Sci. Rep. 6:20301. doi: 10.1038/ srep20301

Ernst, K., Schmid, J., Beck, M., Hägele, M., Hohwieler, M., Hauff, P., et al. (2017a). Hsp70 facilitates trans-membrane transport of bacterial ADP-ribosylating toxins into the cytosol of mammalian cells. Sci. Rep. 7:2724. doi: 10.1038/ s41598-017-02882-y

Ernst, K., Schnell, L., and Barth, H. (2017b). Host cell chaperones Hsp70/Hsp90 and Peptidyl-Prolyl Cis/Trans isomerases are required for the membrane translocation of bacterial ADP-ribosylating toxins. Curr. Top. Microbiol. Immunol. 406, 163-198. doi: 10.1007/82-2016-14

Fischer, G., Wittmann-Liebold, B., Lang, K., Kiefhaber, T., and Schmid, F. X. (1989). Cyclophilin and peptidyl-prolyl cis-trans isomerase are probably identical proteins. Nature 337, 476-478. doi: 10.1038/337476a0

Freeman, B. C., and Morimoto, R. I. (1996). The human cytosolic molecular chaperones hsp90, hsp70 (hsc70) and hdj-1 have distinct roles in recognition of a non-native protein and protein refolding. EMBO J. 15, 2969-2979. doi: 10.1002/j.1460-2075.1996.tb00660.x

Galat, A. (2003). Peptidylprolyl cis/trans isomerases (immunophilins): biological diversity-targets-functions. Curr. Top. Med. Chem. 3, 1315-1347. doi: 10.2174/ 1568026033451862

Handschumacher, R. E., Harding, M. W., Rice, J., Drugge, R. J., and Speicher, D. W. (1984). Cyclophilin: a specific cytosolic binding protein for cyclosporin A. Science 226, 544-547. doi: 10.1126/science.6238408

Harding, M. W., Galat, A., Uehling, D. E., and Schreiber, S. L. (1989). A receptor for the immuno-suppressant FK506 is a cis-trans peptidyl-prolyl isomerase. Nature 341, 758-760. doi: 10.1038/341758a0

Haug, G., Aktories, K., and Barth, H. (2004). The host cell chaperone Hsp90 is necessary for cytotoxic action of the binary iota-like toxins. Infect. Immun. 72, 3066-3068. doi: 10.1128/IAI.72.5.3066-3068.2004

Haug, G., Leemhuis, J., Tiemann, D., Meyer, D. K., Aktories, K., and Barth, H. (2003a). The host cell chaperone Hsp90 is essential for translocation of the 
binary Clostridium botulinum C2 toxin into the cytosol. J. Biol. Chem. 278, 32266-32274. doi: 10.1074/jbc.M303980200

Haug, G., Wilde, C., Leemhuis, J., Meyer, D. K., Aktories, K., and Barth, H. (2003b). Cellular uptake of Clostridium botulinum C2 toxin: membrane translocation of a fusion toxin requires unfolding of its dihydrofolate reductase domain. Biochemistry 42, 15284-15291. doi: 10.1021/bi0354278

Hilger, H., Pust, S., von Figura, G., Kaiser, E., Stiles, B. G., Popoff, M. R., et al. (2009). The long-lived nature of clostridium perfringens iota toxin in mammalian cells induces delayed apoptosis. Infect. Immun. 77, 5593-5601. doi: 10.1128/IAI. 00710-09

Kaiser, E., Böhm, N., Ernst, K., Langer, S., Schwan, C., Aktories, K., et al. (2012). FK506-binding protein 51 interacts with Clostridium botulinum C2 toxin and FK506 inhibits membrane translocation of the toxin in mammalian cells. Cell. Microbiol. 14, 1193-1205. doi: 10.1111/j.1462-5822.2012.01788.x

Kaiser, E., Haug, G., Hliscs, M., Aktories, K., and Barth, H. (2006). Formation of a biologically active toxin complex of the binary Clostridium botulinum C2 toxin without cell membrane interaction. Biochemistry 45, 13361-13368. doi: 10.1021/bi061459u

Kaiser, E., Kroll, C., Ernst, K., Schwan, C., Popoff, M., Fischer, G., et al. (2011). Membrane translocation of binary actin-ADP-ribosylating toxins from Clostridium difficile and Clostridium perfringens is facilitated by cyclophilin A and Hsp90. Infect. Immun. 79, 3913-3921. doi: 10.1128/IAI.05372-11

Kaiser, E., Pust, S., Kroll, C., and Barth, H. (2009). Cyclophilin A facilitates translocation of the Clostridium botulinum C2 toxin across membranes of acidified endosomes into the cytosol of mammalian cells. Cell. Microbiol. 11, 780-795. doi: 10.1111/j.1462-5822.2009.01291.x

Kurazono, H., Hosokawa, M., Matsuda, H., and Sakaguchi, G. (1987). Fluid accumulation in the ligated intestinal loop and histopathological changes of the intestinal mucosa caused by Clostridium botulinum $\mathrm{C} 2$ toxin in the pheasant and chicken. Res. Vet. Sci. 42, 349-353. doi: 10.1016/S0034-5288(18)30717-3

Lang, A. E., Ernst, K., Lee, H., Papatheodorou, P., Schwan, C., Barth, H., et al. (2014). The chaperone Hsp90 and PPIases of the cyclophilin and FKBP families facilitate membrane translocation of Photorhabdus luminescens ADPribosyltransferases. Cell. Microbiol. 16, 490-503. doi: 10.1111/cmi.12228

Li, J., and Buchner, J. (2013). Structure, function and regulation of the hsp90 machinery. Biomed. J. 36, 106-117. doi: 10.4103/2319-4170.113230

Liu, J., Farmer, J. D., Lane, W. S., Friedman, J., Weissman, I., and Schreiber, S. L. (1991). Calcineurin is a common target of cyclophilin-cyclosporin A and FKBP-FK506 complexes. Cell 66, 807-815. doi: 10.1016/0092-8674(91) 90124- $\mathrm{H}$

Mattoo, S., and Cherry, J. D. (2005). Molecular pathogenesis, epidemiology, and clinical manifestations of respiratory infections due to Bordetella pertussis and other Bordetella subspecies. Clin. Microbiol. Rev. 18, 326-382. doi: 10.1128/ CMR.18.2.326-382.2005

Ohishi, I. (1983a). Lethal and vascular permeability activities of botulinum C2 toxin induced by separate injections of the two toxin components. Infect. Immun. 40, 336-339.

Ohishi, I. (1983b). Response of mouse intestinal loop to botulinum C2 toxin: enterotoxic activity induced by cooperation of nonlinked protein components. Infect. Immun. 40, 691-695.

Papatheodorou, P., Barth, H., Minton, N., and Aktories, K. (2018). Cellular uptake and mode-of-action of Clostridium difficile toxins. Adv. Exp. Med. Biol. 1050, 77-96. doi: 10.1007/978-3-319-72799-8-6

Pratt, W. B., and Toft, D. O. (2003). Regulation of signaling protein function and trafficking by the hsp90/hsp70-based chaperone machinery. Exp. Biol. Med. 228, 111-133. doi: 10.1177/153537020322800201
Prell, E., Kahlert, V., Rücknagel, K. P., Maleševič, M., and Fischer, G. (2013). Fine tuning the inhibition profile of cyclosporine A by derivatization of the $\mathrm{MeBmt}$ residue. ChemBioChem 14, 63-65. doi: 10.1002/cbic.201200621

Reuner, K. H., Presek, P., Boschek, C. B., and Aktories, K. (1987). Botulinum C2 toxin ADP-ribosylates actin and disorganizes the microfilament network in intact cells. Eur. J. Cell Biol. 43, 134-140.

Sandvig, K., and Olsnes, S. (1980). Diphtheria toxin entry into cells is facilitated by low pH. J. Cell Biol. 87, 828-832. doi: 10.1083/jcb.87.3.828

Schiene-Fischer, C. (2015). Multidomain Peptidyl Prolyl cis/trans isomerases. Biochim. Biophys. Acta 1850, 2005-2016. doi: 10.1016/j.bbagen.2014.11.012

Schleberger, C., Hochmann, H., Barth, H., Aktories, K., and Schulz, G. E. (2006). Structure and action of the binary $\mathrm{C} 2$ toxin from Clostridium botulinum. J. Mol. Biol. 364, 705-715. doi: 10.1016/j.jmb.2006.09.002

Schopf, F. H., Biebl, M. M., and Buchner, J. (2017). The HSP90 chaperone machinery. Nat. Rev. Mol. Cell Biol. 18, 345-360. doi: 10.1038/nrm.2017.20

Schreiber, S. L., Liu, J., Albers, M. W., Karmacharya, R., Koh, E., Martin, P. K., et al. (1991). Immunophilin-ligand complexes as probes of intracellular signaling pathways. Transplant. Proc. 23, 2839-2844.

Schuster, M., Schnell, L., Feigl, P., Birkhofer, C., Mohr, K., Roeder, M., et al. (2017). The Hsp90 machinery facilitates the transport of diphtheria toxin into human cells. Sci. Rep. 7:613. doi: 10.1038/s41598-017-00780-x

Simpson, L. L. (1982). A comparison of the pharmacological properties of Clostridium botulinum type C1 and C2 toxins. J. Pharmacol. Exp. Ther. 223, 695-701.

Söderberg, O., Leuchowius, K.-J., Gullberg, M., Jarvius, M., Weibrecht, I., Larsson, L.-G., et al. (2008). Characterizing proteins and their interactions in cells and tissues using the in situ proximity ligation assay. Methods 45, 227-232. doi: 10.1016/j.ymeth.2008.06.014

Songer, J. G. (1996). Clostridial enteric diseases of domestic animals. Clin. Microbiol. Rev. 9, 216-234. doi: 10.1128/CMR.9.2.216

Stiles, B. G. (2017). Clostridial binary toxins: basic understandings that include cell surface binding and an internal "Coup de Grâce.". Curr. Top. Microbiol. Immunol. 406, 135-162. doi: 10.1007/82-2016-11

Williamson, D. S., Borgognoni, J., Clay, A., Daniels, Z., Dokurno, P., Drysdale, M. J., et al. (2009). Novel adenosine-derived inhibitors of $70 \mathrm{kDa}$ heat shock protein, discovered through structure-based design. J. Med. Chem. 52, 1510-1513. doi: 10.1021/jm801627a

World Health Organization [WHO]. (2016). Pertussis vaccines: WHO position paper, August 2015-recommendations. Vaccine 34, 1423-1425. doi: 10.1016/ j.vaccine.2015.10.136

Zornetta, I., Brandi, L., Janowiak, B., Dal Molin, F., Tonello, F., Collier, R. J., et al. (2010). Imaging the cell entry of the anthrax oedema and lethal toxins with fluorescent protein chimeras. Cell. Microbiol. 12, 1435-1445. doi: 10.1111/j. 1462-5822.2010.01480.x

Conflict of Interest Statement: The authors declare that the research was conducted in the absence of any commercial or financial relationships that could be construed as a potential conflict of interest.

Copyright (c) 2018 Ernst, Kling, Landenberger and Barth. This is an open-access article distributed under the terms of the Creative Commons Attribution License (CC BY). The use, distribution or reproduction in other forums is permitted, provided the original author(s) and the copyright owner(s) are credited and that the original publication in this journal is cited, in accordance with accepted academic practice. No use, distribution or reproduction is permitted which does not comply with these terms. 